\title{
Epithelioid Cell Melanoma
}

National Cancer Institute

\section{Source}

National Cancer Institute. Epithelioid Cell Melanoma. NCI Thesaurus. Code C4236.

A melanoma characterized by the presence of malignant large epithelioid melanocytes. 